\title{
KARAKTERISTIK KOMPOSIT SERAT KULIT POHON WARU (HIBISCUS TILIACEUS) BERDASARKAN JENIS RESIN SINTETIS TERHADAP KEKUATAN TARIK DAN PATAHAN KOMPOSIT
}

\author{
Arief Rizki Fadhillah ${ }^{1}$, Sofyan Arief Setiyabudi², Anindito Purnowidodo 2 \\ 1, 2 Teknik Mesin Fakultas Teknik Universitas Brawijaya \\ JI. MT. Haryono No. 167, Malang 65145, Jawa Timur-Indonesia \\ Telp. 0341-551611 / fax. 0341-565420 \\ E-mail: Arfadris11@gmail.com
}

\begin{abstract}
The fiber composite of hibiscus's bark is the material that comprises synthetic resin as a matrix and hibiscus's bast fiber as reinforcement. The hibiscus's bast fiber have the excellent potency regarding the strength that is employed as reinforcement. Four types of synthetic resin were used in this study, polyester BTQN 157, bisphenol A LP-1Q-EX, ripoxy R-802, and epoxy. The ratio of mass fractions between fiber and resin was 60:40. The initial treatment of the bast fiber hibiscus was immersed in $6 \%$ of $\mathrm{NaOH}$ solution for two hours. The composites were manufactured through vaccum bagging process. Tensile strength and fracture mode of composites were investigated. The fiber composites of hibiscus tree bark with bisphenol A LP$1 Q-E X$ resin has the best tensile strength and epoxy resin have a small fracture area were obtained.
\end{abstract}

Keywords: composite, bast fibers hibiscus, synthetic resin, tensile strength, vacuum bagging

\section{PENDAHULUAN}

Komposit serat kulit pohon waru (Hibiscus tiliaceus) adalah material gabungan antara serat kulit pohon waru dan resin sintetis. Kulit batang waru dihasilkan dari proses pengelupasan dari kayu dan mengalami proses perendaman dalam air selama kurang lebih selama 30 hari [1]. Material ini juga sering disebut dengan komposit serat alam atau natural fiber composites (NFC). Komposit serat alam merupakan salah satu jenis komposit yang termasuk kedalam komposit berbasis matrik polimer yang dikombinasikan dengan serat alam. Komposit serat alam pada dasarnya sama dengan komposit pada umumnya, yaitu kombinasi dari dua atau lebih material dengan sifat mekanik yang berbeda serta mengkombinasikan sifat-sifat mekanik tersebut akan menghasilkan sifat mekanik yang lebih baik secara keseluruhan dari material komposit [2].

Serat kulit pohon waru telah terbukti dapat digunakan sebagai reinforcement dalam komposit. Komposit berpenguat serat kulit waru kontinyu laminat dengan perlakuan alkali bermatriks polyester menghasilkan peningkatan kekuatan tarik dan kekuatan bending komposit. Terlebih dahulu komposit telah mengalami yang diperoleh untuk perlakuan alkalisasi serat menggunakan $\mathrm{NaOH} 5 \%$ selama 2 jam [3].

Pengujian pada papan partikel yang terbuat dari serbuk kalsium karbonat $\left(\mathrm{CaCO}_{3}\right)$ dan serat kulit waru dengan resin polyester juga menunjukkan peningkatan kekuatan. Komposit yang dihasilkan memiliki kekuatan lentur sebesar 117,10 Mpa dan kekuatan impak mencapai $3,4 \mathrm{~kJ} / \mathrm{m}^{2}$. Sedangkan kekuatan tekan 43,02MPa dan kekuatan tarik sebesar 37,53 Mpa. Hal ini juga membuktikan penggunaan serat kulit pohon waru memiliki pengaruh terhadap kekuatan jika digunakan sebagai reinforcement pada komposit [4].

Biokomposit dengan menggunakan serat kulit waru bermatrik pati ubi kayu berhasil meningkatkan kekuatan bending yaitu sebesar $50,58 \mathrm{MPa}$. [5]. Waktu perendaman serat juga memberikan pengaruh terhadap kekuatan tarik. Perendaman serat pohon waru pada air laut pH 6 mengakibatkan timbulnya celah antar sub serat dan waktu perendaman menyebabkan jarak antar subcelah semakin tinggi. Perendaman meningkatkan kekuatan tarik tetapi semakin lama perendaman kekuatan tarik semakin menurun [6].

Dari beberapa penelitian terdahulu diatas maka serat kulit pohon waru memiliki potensi 
yang sangat baik sebagai reinforced pada komposit serat alam, akan tetapi perlu adanya pengembangan penelitian mengenai jenis matrik yang digunakan pada komposit sehingga akan menghasilkan ikatan antar serat dan matrik yang lebih baik. Penelitian ini bertujuan untuk mengetahui pengaruh jenis resin terhadap kekuatan tarik komposit serat kulit pohon waru .

\section{METODOLOGI PENELITIAN}

Komposit serat kulit pohon waru dibuat dengan variasi jenis resin sintetis, antara lain : resin poliester BTQN 157, resin bisphenol $A$ LP-1Q-EX, resin ripoksi $\mathrm{R}-802$, dan resin epoksi A dan B. Orientasi serat yang digunakan adalah unidirectional. Fraksi yang digunakan adalah fraksi massa dengan perbandingan serat dan matrik sebesar 60 : 40. serat kulit pohon waru diberi perlakuan perendaman alkali $\mathrm{NaOH}$ sebesar $6 \%$ selama 120 menit. Spesimen uji tarik komposit menggunakan standar ASTM D638-03 Type I sesuai dengan Gambar 1 [7].

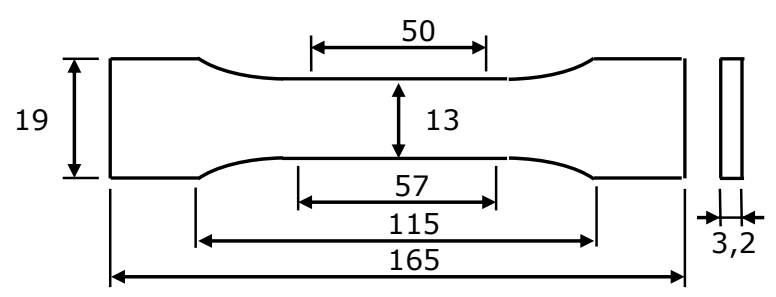

Gambar 1 Spesimen uji tarik komposit (mm)

Proses pembuatan komposit mengunakan metode Vacuum Bagging dengan tekanan mencapai -27 Atm. Resin dalam wadah resin disalurkan melalui flow tube menuju katup masuk pada cetakan yang telah ditutup dengan plastik bagging. Resin akan melalui katup keluar yang telah disambungkan oleh flow tube menuju resin trap dan dalam kondisi tersambung pada vaccum pump dengan flow tube.

Resin sintetis yang digunakan memiliki komposisi yang berbeda. Resin poliester BTQN 157 memiliki komposisi resin dan mekpo. Resin bisphenol LP-1Q-EX dan resin ripoksi R-802 memiliki komposisi resin, promoter, mekpo. Resin epoksi A dan B memiliki komposisi resin dan hardener.

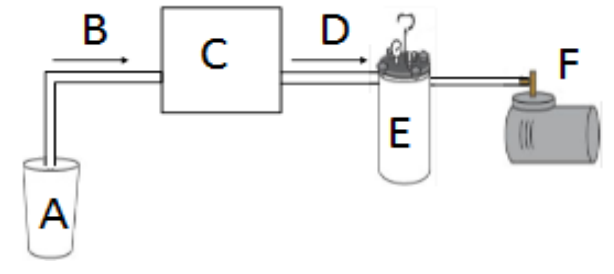

Keterangan :

A : wadah resin

B : flow tube ke katup masuk cetakan

C : cetakan

D : flow tube dari katup keluar cetakan ke vacum trap

E : vacum trap

$F$ : vacum pump

Gambar 2 Proses vacuum bagging

Pengujian yang dilakukan dalam penelitian ini adalah uji tarik komposit menggunakan electro-hydraulic servo-control static \& dynamic Universal testing machine, Foto Makro Patahan menggunakan kamera Canon EOS 700D Kit (EF S18-55 IS STM) dengan lensa Canon EF Macro 100mm F2.8L IS USM.

\section{HASIL DAN PEMBAHASAN}

\section{A. Kekuatan tarik komposit dan jenis matrik}

Berdasarkan hasil uji tarik komposit serat kulit pohon waru dengan variasi jenis resin didapatkan grafik tegangan-regangan ditunjukkan pada Gambar 3 berikut :

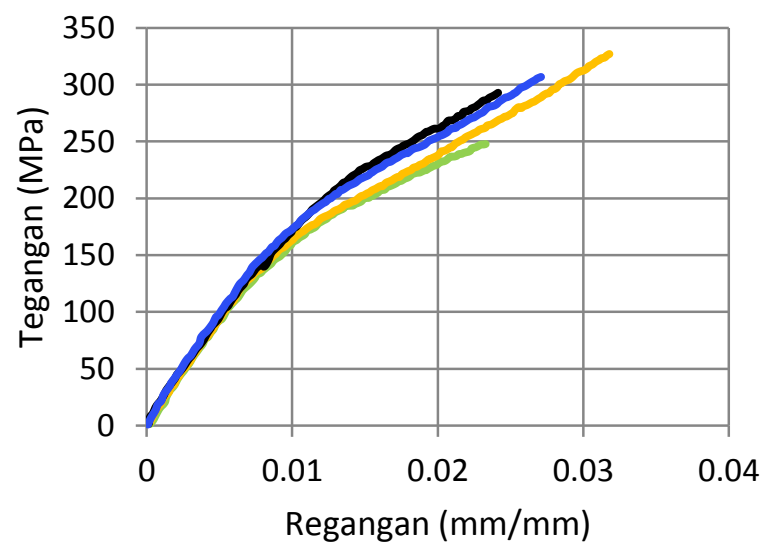

Resin poliester $\longrightarrow$ Resin ripoksi
Resin bisphenol
Resin epoksi

Gambar 3 Tegangan-regangan komposit serat waru variasi jenis resin 
Tegangan-regangan yang dihasilkan dari uji tarik komposit serat waru variasi jenis resin dapat dilihat pada Gambar 3. Berdasarkan grafik tersebut dapat diketahui bahwa nilai tegangan tertinggi terdapat pada komposit dengan resin bisphenol, sedangkan komposit dengan resin poliester menghasilkan nilai tegangan terendah. Nilai regangan yang dihasilkan oleh komposit dengan 4 jenis resin juga memiliki nilai regangan yang sama dengan nilai tegangan.

Berdasarkan grafik tegangan-regangan pada komposit serat kulit pohon waru dengan variasi jenis resin sintetis didapatkan kekuatan tarik dan regangan maksimum dari komposit pada masing-masing jenis resin. Komposit dengan resin poliester memiliki nilai kekuatan tarik sebesar 247.81 MPa. Komposit dengan resin bisphenol memiliki kekuatan tarik sebesar 327.12 MPa. Komposit dengan resin ripoksi memiliki kekuatan tarik sebesar 292.80 $\mathrm{MPa}$. Komposit dengan resin epoksi memiliki kekuatan tarik sebesar $306.76 \mathrm{MPa}$.

Regangan maksimum resin poliester, resin bisphenol dan resin ripoksi masingmasing adalah sebesar $0.0233 \mathrm{~mm} / \mathrm{mm}$, $0.0318 \mathrm{~mm} / \mathrm{mm}$ dan $0.0241 \mathrm{~mm} / \mathrm{mm}$. Resin epoksi menghasilkan regangan maksimum sebesar $0.0271 \mathrm{~mm} / \mathrm{mm}$. Komposit dengan regangan maksimum tertinggi terdapat pada komposit dengan resin bispheol, sedangkan regangan maksimum terendah terdapat pada komposit dengan resin Poliester.

Berdasarkan hasil kekuatan tarik dan regangan maksimum diatas, maka dapat diketahui bahwa komposit serat kulit pohon waru dengan resin bisphenol memiliki kekuatan tarik dan regangan maksimum tertinggi, sedangkan yang terendah adalah komposit dengan resin poliester. Hal ini dikarenakan, resin bisphenol memiliki sifat lentur dan mulur yang menjadikan regangan dan kuat tarik akan lebih tinggi serta ikatan yang dihasilkan antara matrik bisphenol dan serat waru lebih baik daripada resin lainnya.

Pada Gambar 3 dapat dilihat bahwa grafik tegangan regangan yang dihasilkan masingmasing komposit jenis resin memiliki kecenderungan yang sama didaerah elastis. perubahan tegangan komposit jenis resin terjadi pada saat beban tarik yang diberikan mencapai tegangan yield. Komposit serat waru resin poliester menghasilkan tegangan yield sebesar 102.64 MPa dengan regangan 0.0055 $\mathrm{mm} / \mathrm{mm}$. Komposit serat waru resin bisphenol menghasilkan tegangan yield sebesar 125.55 $\mathrm{MPa}$ dengan regangan $0.0068 \mathrm{~mm} / \mathrm{mm}$. Sedangkan komposit serat waru resin ripoksi menghasilkan tegangan yield sebesar 139.90 $\mathrm{MPa}$ dengan regangan $0.0076 \mathrm{~mm} / \mathrm{mm}$. Untuk komposit serat waru resin ripoksi menghasilkan tegangan yield sebesar 128.08 $\mathrm{MPa}$ dengan regangan $0.0067 \mathrm{~mm} / \mathrm{mm}$.

Tegangan dan regangan yield yang dihasilkan akan mempengaruhi modulus elastisitas dari masing-masing komposit jenis resin seperti terdapat pada Gambar 4 berikut.

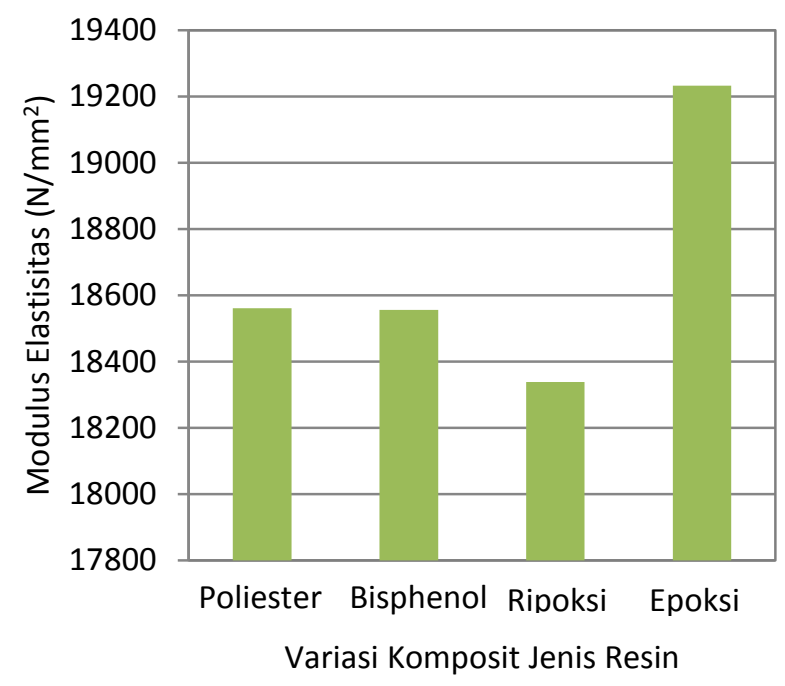

Gambar 4 Modulus elastisitas komposit serat waru variasi jenis resin

Gambar 4 diatas menjelaskan modulus elastisitas komposit serat waru resin polyester sebesar $18561.49 \mathrm{~N} / \mathrm{mm}^{2}$. Modulus elastisitas komposit serat waru resin bisphenol sebesar $18555.98 \mathrm{~N} / \mathrm{mm}^{2}$. Modulus elastisitas komposit serat waru resin ripoksi sebesar 18338.32 $\mathrm{N} / \mathrm{mm}^{2}$. Modulus elastisitas komposit serat waru resin epoksi sebesar $19233.20 \mathrm{~N} / \mathrm{mm}^{2}$.

Komposit serat waru resin epoksi menghasilkan modulus elastisitas tertinggi, sedangkan komposit serat waru resin ripoksi menghasilkan modulus elastisitas terendah. Hal ini dikarenakan modulus elastisitas dipengaruhi oleh tegangan dan regangan yield yang dihasilkan oleh komposit, sehingga semakin tinggi tegangan dan regangan yield maka modulus elastisitas akan rendah. Kondisi tersebut akan mempengaruhi tegangan dan regangan keseluruhan dari komposit. 
Selain itu, tegangan-regangan jenis resin mempengaruhi kekuatan tarik dan regangan maksimum pada komposit serat kulit pohon waru dengan variasi jenis resin. Hal ini dapat dilihat pada Gambar 5 yang menjelaskan tentang tegangan-regangan resin tanpa serat.

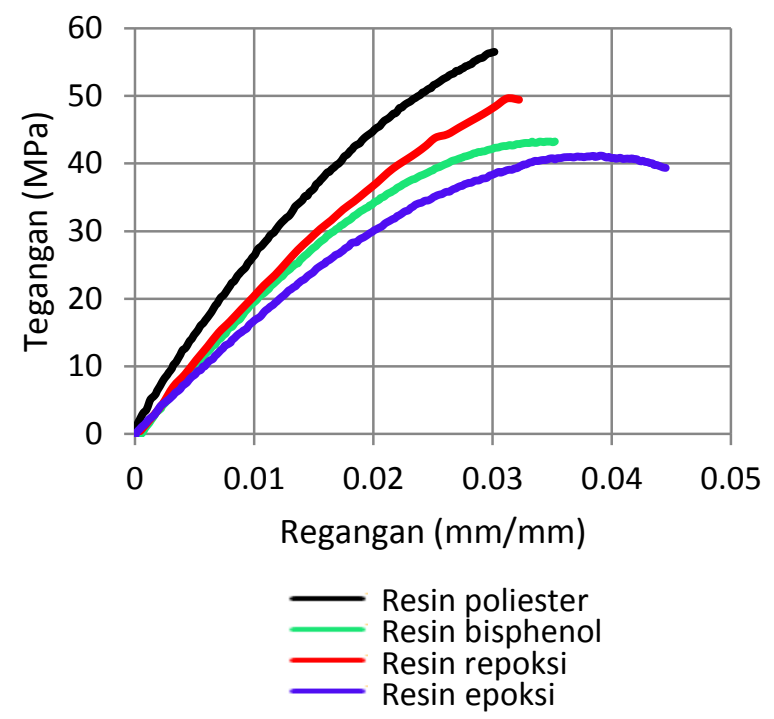

Gambar 5 Tegangan-regangan jenis resin tanpa serat

Pada grafik tersebut menjelaskan bahwa resin poliester memiliki tegangan tertinggi akan tetapi menghasilkan regangan terendah. Resin epoksi menghasilkan tegangan terendah akan tetapi memiliki regangan tertinggi. Kekuatan tarik dan regangan tertinggi pada komposit dengan jenis resin bisphenol memiliki tegangan terendah akan tetapi memiliki regangan lebih baik dibandingkan dengan resin poliester. Hal ini menjadikan resin bisphenol akan mampu menerima beban tarik lebih baik, karena regangan akan menjadi lebih besar.

\section{B. Analisa ikatan serat dan matrik}

Berdasarkan hasil uji tarik, maka dapat dibuktikan dari ikatan antar serat dan matrik pada masing-masing komposit jenis resin seperti ditunjukkan pada Gambar 6. Selain konsentrasi alkali $\mathrm{NaOH}$ yang mempengaruhi ikatan antara serat dan matrik, maka jenis resin sintetis juga mempengaruhi ikatan yang terdapat dalam komposit.

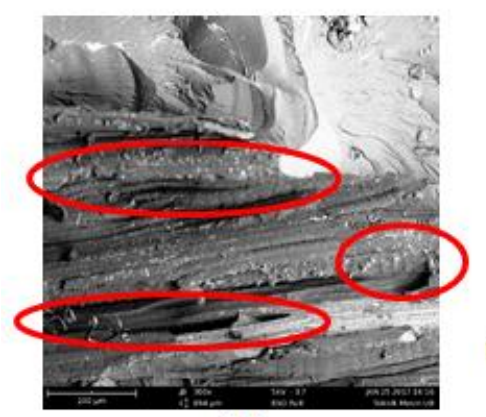

(a)

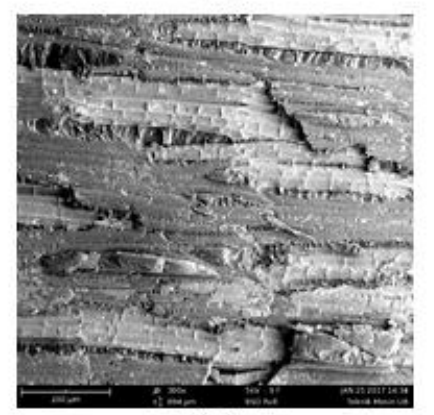

(b)

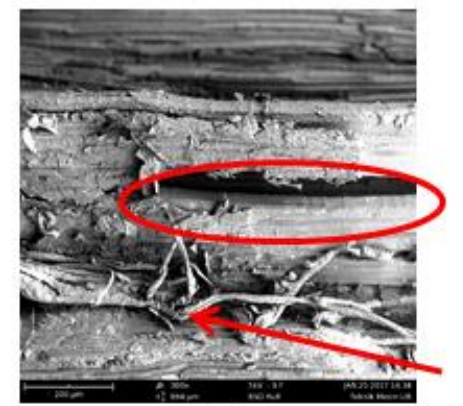

(c)

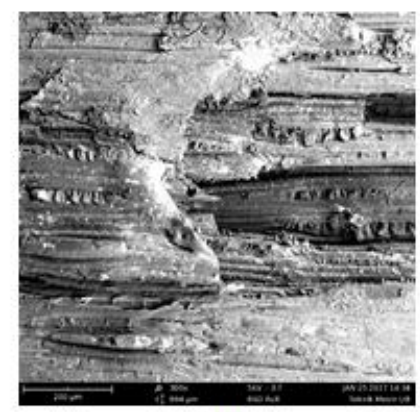

(d)
Rongga serat tidak terisi resin
Rongga serat tidak terisi resin

Serat tidak terikat resin
Gambar 6 Hasil foto sem pembesaran 300x pada ikatan komposit antara serat kulit pohon waru dan jenis resin sintetis,
(a) Resin poliester BTQN 157,

(b) Resin bisphenol LP-1Q-EX

(c) Resin ripoksi R-802,

(d) Resin Epoksi 
Gambar 6 (a) menjelasakan ikatan yang terjadi antar serat dan resin poliester terdapat rongga pada serat kulit pohon waru yang tidak terisi oleh resin. Resin bisphenol memiliki kekuatan tarik tertinggi dikarenakan ikatan yang terjadi antar serat dan resin sangat baik seperti ditunjukkan pada Gambar 6 (b). Rongga pada serat kulit pohon waru terisi secara keseluruhan oleh resin yang menyebabkan kekuatan tarik akan lebih baik. Serat yang tidak terikat oleh resin dan terdapatnya rongga serat yang tidak terisi oleh resin menjadikan komposit dengan resin ripoksi menghasilkan kekuatan tarik terendah seperti Gambar 6 (c), hal ini menjadikan ikatan antar serat dan matrik tidak sempurna. Komposit dengan resin epoksi memiliki regangan yang tingi disebabkan karena resin dapat memasuki rongga-rongga serat dengan baik dan sempurna seperti ditunjukkan pada Gambar 6(d).

\section{Analisa patahan komposit}

Berdasarkan hasil uji tarik komposit serat kulit pohon waru yang telah dilakukan, maka patahan uji tarik pada variasi jenis resin dapat dilihat pada Gambar 7. Patahan yang terjadi pada seluruh variasi jenis resin tidak terjadi patahan yang terpusat pada satu titik atau tidak dapat diprediksi posisi patahan kecuali patahan dengan resin Epoksi A dan B yang memiliki fracture area lebih kecil. Hal ini dikarenakan pada resin epoksi ada dugaan dimana resin dapat mendistribusikan beban yang diberikan pada serat secara merata dan nilai toleransi terhadap kekuatan serat lebih tinggi. Resin epoksi memiliki viskositas yang tinggi, sehingga pada proses aliran resin di vaccum bagging menghasilkan waktu yang lebih besar dibandingkan resin lainnya. Sehingga dapat direkomendasikan untuk serat kulit pohon waru menggunakan resin Epoksi $A$ dan B.

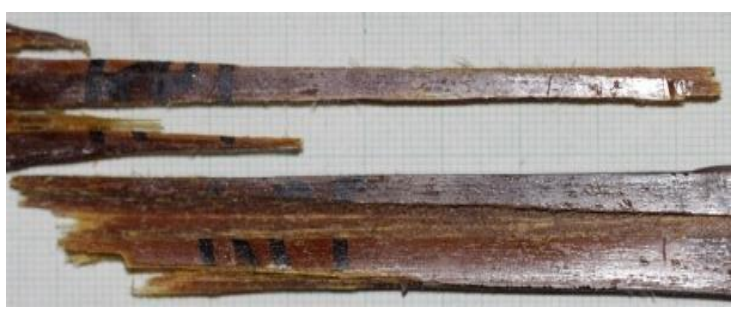

(a)

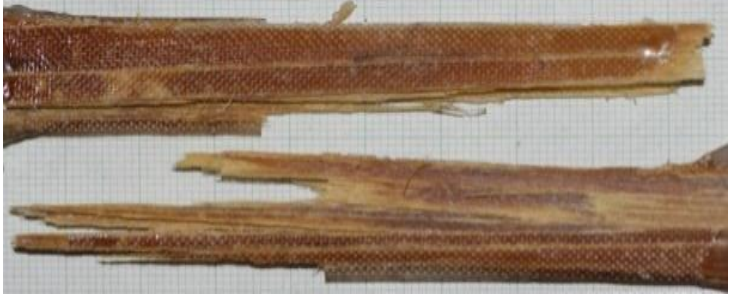

(b)

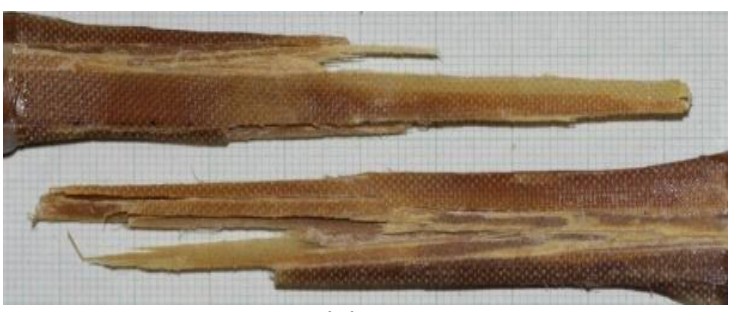

(c)

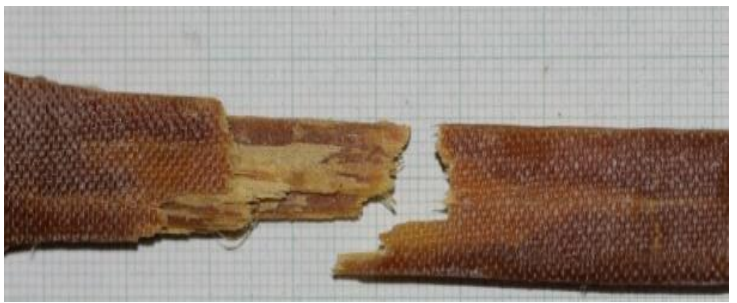

(d)

Gambar 7 Patahan uji tarik komposit serat kulit pohon waru variasi jenis resin,

(a) resin poliester BTQN 157,

(b) resin bisphenol LP-1Q-EX,

(c) resin ripoksi $\mathrm{R}-802$,

(d) resin epoksi A dan B

\section{Analisa fase patahan komposit}

Fase patahan komposit berdasarkan diagram tegangan-regangan dapat dilihat pada Gambar 8 a-d. Fase patahan komposit serat kulit pohon waru menggunakan resin poliester dapat dilihat pada Gambar 8 (a). Pada saat beban tarik diberikan dan mencapai tegangan 102.64 MPa, maka komposit tidak mengalami retak. Pada saat tegangan mencapai 164.90 MPa terjadi awal retak di daerah ujung kanan atas necking. Rambatan retak terjadi pada saat tegangan mencapai 213.23 MPa. Fracture terjadi secara keseluruhan di daerah necking saat tegangan ultimate yaitu 247.81 $\mathrm{MPa}$. 

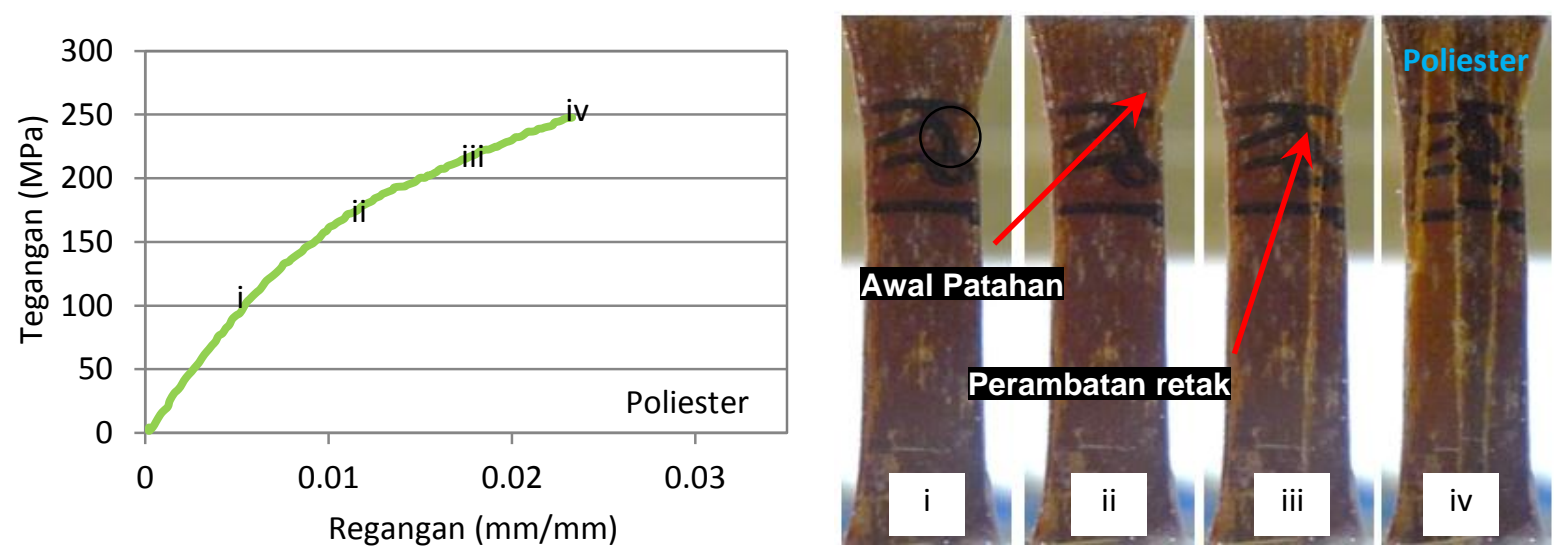

(a)
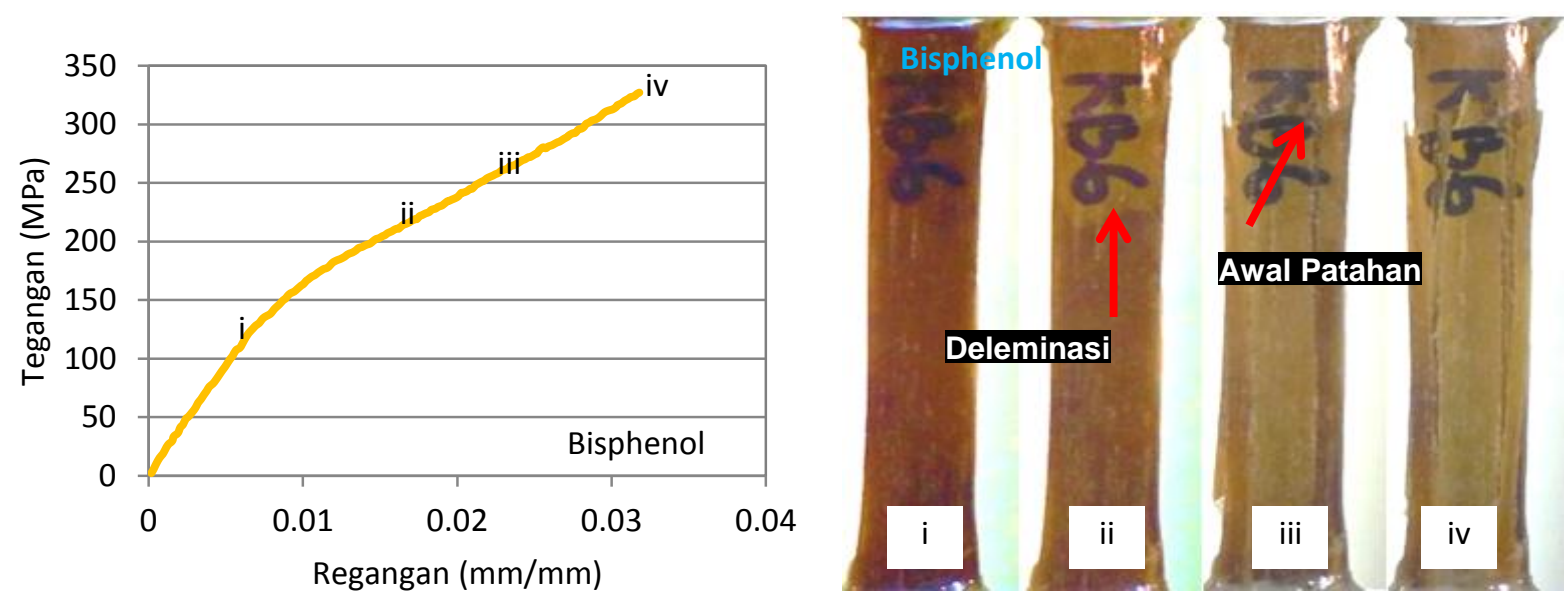

(b)
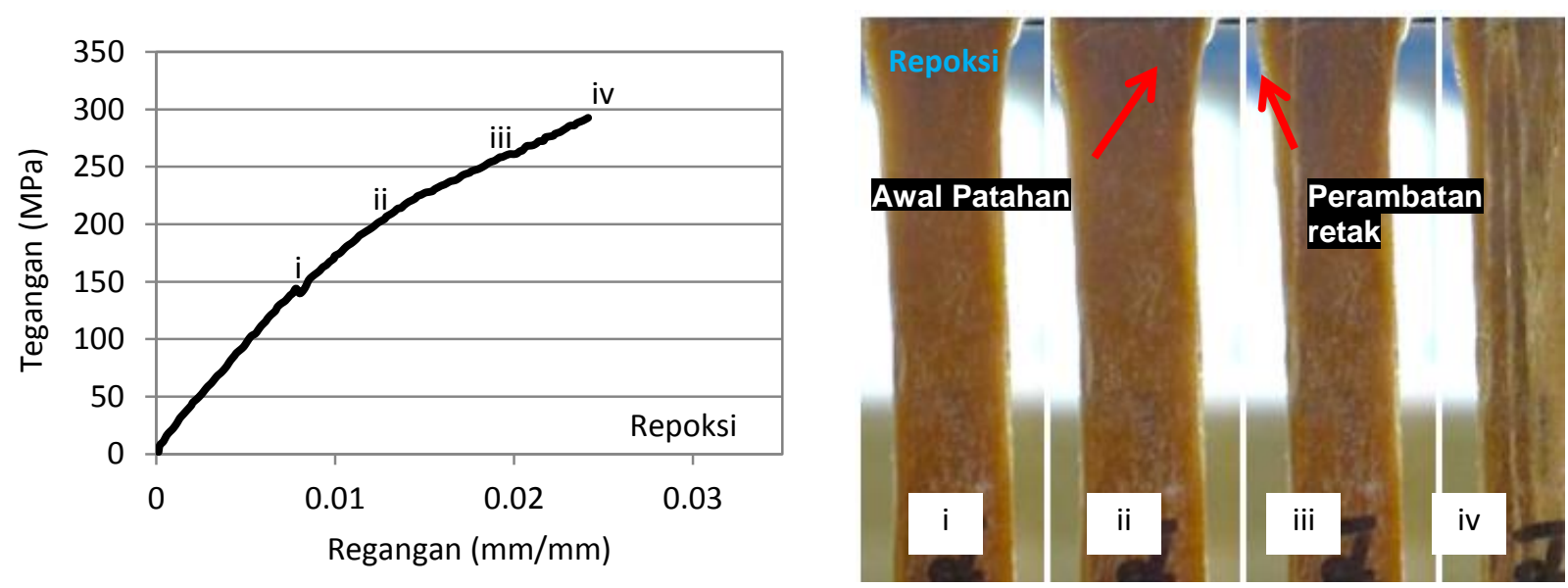

(c) 

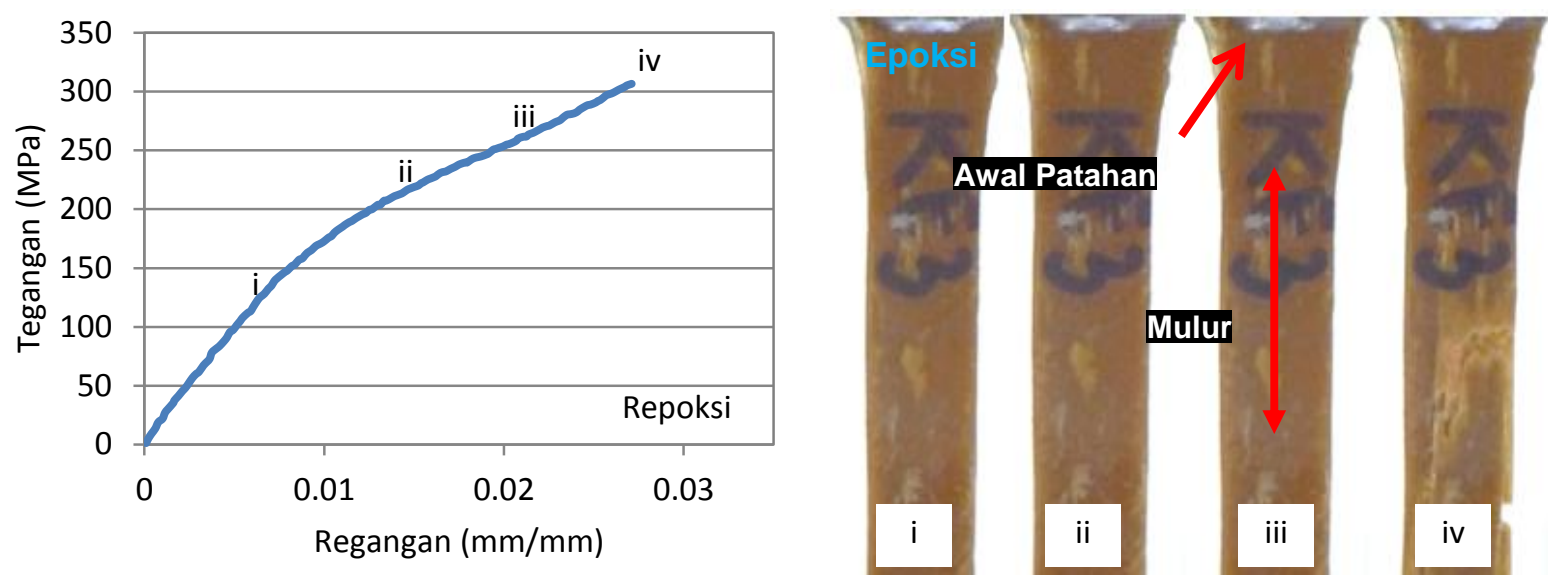

(d)

Gambar 8 Fase patahan spesimen berdasarkan grafik tegangan regangan pada uji tarik komposit serat kulit pohon waru variasi jenis resin, (a) resin poliester BTQN 157

(b) resin bisphenol LP-1Q-EX (c) resin ripoksi R-802 (d) resin epoksi

Komposit serat kulit pohon waru menggunakan resin bisphenol memiliki tegangan tertinggi. Hal ini mempengaruhi fase patahan yang terjadi pada komposit yang dapat dilihat pada Gambar 8 (b), retak tidak terjadi pada komposit saat tegangan mencapai 125.55 MPa. Awal patahan terjadi pada saat komposit mencapai tegangan $210.89 \mathrm{MPa}$ yaitu menghasilkan terjadinya deleminasi di sisi ujung necking. Deleminasi marambat pada area necking yang menimbulkan retak saat tegangan mencapai $268.17 \mathrm{MPa}$. Fracture terjadi secara total pada seluruh bagian necking spesimen komposit saat mencapai tegangan ultimate sebesar $327.12 \mathrm{MPa}$.

Komposit serat kulit pohon waru dengan resin ripoksi $\mathrm{R}-802$ memiliki fase patahan komposit yang dapat dilihat pada Gambar 8 (c). Retak tidak terjadi pada saat tegangan komposit mencapai $139.90 \mathrm{MPa}$. Awal patahan terjadi pada saat komposit mencapai tegangan $209.09 \mathrm{MPa}$ dengan menghasilkan retak pada ujung sisi kanan necking. Rambatan retak terjadi pada area necking yang bersebelahan dengan awal retak sebelumnya pada saat tegangan mencapai 258.64 MPa. Fracture terjadi secara total pada seluruh bagian necking spesimen komposit saat mencapai tegangan ultimate sebesar 292.80 MPa.
Fase patahan komposit serat kulit pohon waru dengan resin epoksi dapat dilihat pada Gambar 8 (d). Komposit dengan resin epoksi ini menghasilkan ketangguhan material yang sangat baik, hal ini dapat dilihat pada fase patahan yang terjadi tidak terjadi tanda-tanda awal patahan berupa retak pada daerah necking akan tetapi terjadi penambahan panjang material atau mulur. Pada saat tegangan 128.08 $\mathrm{MPa}, \quad 207.20 \mathrm{MPa}$ dan $256.61 \mathrm{MPa}$, maka tidak terjadi timbulnya retak. Fracture terjadi secara langsung dan total pada seluruh bagian necking spesimen komposit saat mencapai tegangan ultimate sebesar $306.76 \mathrm{MPa}$.

Berdasarkan hasil diatas, maka dapat diketahui bahwa pada komposit variasi jenis resin memiliki awal retak rata-rata pada sisi ujung daerah necking kecuali komposit yang menggunakan resin epoksi. Serat kulit pohon waru dengan jenis resin memiliki pengaruh terhadap fase patahan yang terjadi pada komposit, karena fase patahan pada masingmasing jenis resin akan menghasilkan tegangan yang berbeda. Hal ini dikarenakan ikatan yang terjadi antar serat dan jenis resin sintetis berbeda yang menyebabkan tegangan akan dipengaruhi oleh jenis resin yang digunakan sebagai matrik pada komposit serat kulit pohon waru. 


\section{KESIMPULAN}

Berdasarkan hasil penelitian dari pengujian tarik komposit yang terbuat dari serat kulit pohon waru (hibiscus tiliaceus) dengan variasi jenis resin sintetis dapat ditarik kesimpulan yaitu:

1. Jenis resin sintetis yang digunakan sebagai matrik pada komposit serat kulit pohon waru mempengaruhi kekuatan tarik dan patahan komposit.

2. Dari segi kekuatan tarik komposit maka dapat direkomendasikan menggunakan resin bisphenol LP-1Q-EX, karena memiliki kekuatan tarik yang baik serta memiliki kemuluran yang sangat baik.

3. Dari segi area patahan yang terjadi, maka dapat direkomendasikan menggunakan resin Epoksi $A$ dan $B$, hal ini dikarenakan pada komposit dengan resin poliester BTQN 157, Resin Bisphenol LP-1Q-EX dan Resin Ripoksi R-802 memiliki area patahan yang tidak dapat diprediksi, sedangkan resin epoksi $A$ dan $B$ memiliki area patahan yang lebih kecil.

\section{DAFTAR PUSTAKA}

[1] Suwandi, \& Hendrati, R. L. (2014). Perbanyakan Vegetatif Dan Penanaman Waru (Hibiscus tiliaceus) Untuk Kerajinan Dan Obat. Jakarta: IPB Press.

[2] Tambyrajah, D. (2015). Indulge \& Explore Natural Fiber Composites "An invitation to product designers". The Netherlands: NFCDesign Platform.
[3] Nurudin, A., Sonief, A. A., \& Atmodjo, W. Y. (2011). Karakterisasi Kekuatan Mekanik Komposit Berpenguat Serat Kulit Waru (Hibiscus Tiliaceus) Kontinyu Laminat Dengan Perlakuan Alkali Bermatriks Polyester. Jurnal Rekayasa Mesin Vol.II, No. 3 , 209-217.

[4] Warkum. (2013). Tesis : Pembuatan Dan Karakterisasi Papan Partikel Dari Serbuk Kalsium Karbonat (CaCO3) Serat Kulit Waru (Hibiscus Tiliaceus) Dengan Resin Polyester. Medan: Program Pasca Sarjana Fakultas Matematika dan IImu Pengetahuan Alam Universitas Sumatera Utara.

[5] Rianto, A., Soeparman, S., \& Sugiarto. (2011). Karakterisasi Kekuatan Bending dan Hidrofobisitas Komposit Serat Kulit Waru (Hibiscus tiliaceus) Kontinyu Bermatrik Pati Ubi Kayu. Jurnal Rekayasa Mesin Vol.2, No. 2 - ISSN 0216-468X, 130-136.

[6] Prasetyo, A., Purwanto, H., Respati, S. M. B. (2016). Pengaruh Waktu Perendaman Serat Kulit Pohon Waru (Hibiscus tiliaceus) Pada Air Laut Terhadap Struktur Mikro dan Kekuatan Tarik. Jurnal Momentum Vol. 12, No. 2, Oktober 2016 ISSN 0216-7395, 42-47.

[7] Book standard ASTM D638-03 Type I 